\title{
Variola Minor in England and Wales: The Geographical Course of a Smallpox Epidemic and the Impediments to Effective Disease Control, 1920-1935
}

Sarah Rafferty*, Matthew R Smallman-Raynor* and Andrew D Cliff ${ }^{\dagger}$

$\underline{\text { Positions and affiliations }}$

*School of Geography, University of Nottingham, University Park, Nottingham, NG7 2RD, UK.

†Department of Geography, University of Cambridge, Downing Place, Cambridge, CB2 3EN, UK.

Corresponding author

M R Smallman-Raynor, School of Geography, University of Nottingham, University Park, Nottingham, NG7 2RD, UK. Email: matthew.smallman-raynor@nottingham.ac.uk. Tel.: +44 (0)1159515427. 


\section{Highlights}

- Examines the spread of the last national epidemic of smallpox in England and Wales

- Maps the geographical course of the epidemic at the county level

- Explores how smallpox evaded well-established protocols for disease control

- Identifies a range of control impediments in the epidemic focus of Gloucestershire

- Demonstrates the role of professional and public cooperation in disease control 


\begin{abstract}
The 1920-1935 epidemic of variola minor in England and Wales is a prime example of a major smallpox outbreak that spread in a national population with waning levels of vaccine-induced immunity. This paper examines the geographical course of the epidemic and the reasons why the disease was able to evade the (then) established protocols for smallpox control in many local government areas. The control issue is examined using archival records from the English county of Gloucestershire, where smallpox spread out of effective control in 1923. At the national level, our analysis demonstrates that the build-up (1920-1927) of the epidemic was characterised by a persistent core of reported cases of high intensity in the counties of central and northern England. Epidemic fade-out (1928-1935) was associated with an accelerated shift of disease activity to London and the southeast. Set against this national context, Gloucestershire represented a microcosm of the impediments to smallpox control in inter-war Britain. Here, a series of sociodemographic and administrative factors operated to impede disease control. Our study demonstrates the potential fragility of established disease control systems and the importance of professional and public cooperation, sometimes in the face of vehemently contested evidence over the nature of a disease and the means of its control, in attempts to limit the spread of epidemics.
\end{abstract}

Keywords: Disease control; Epidemic; Medical geography; Gloucestershire; Location quotients; Public health; Stamping out; Vaccination. 
The 1920-1935 epidemic of smallpox in England and Wales is a prime example of a major smallpox epidemic that spread in a national population with waning levels of vaccine-induced immunity. The British Vaccination Acts of 1898 and 1907 had relaxed the mid nineteenthcentury laws on the compulsory vaccination of infants so that, by the start of the 1920s, some 2.5 million or more children under twelve years old were legally exempted from smallpox vaccination in England and Wales. ${ }^{1}$ It was at about this time that a distinctly mild form of smallpox, known as variola minor, began to spread through the susceptible population of Britain. ${ }^{2}$ The ensuing epidemic was associated with well over 81,000 notified smallpox cases (including 209 deaths) in almost nine hundred local government areas of England and Wales. ${ }^{3}$ In some of these affected areas the outbreaks were rapidly contained and yielded just a few cases. In many others, however, the disease seemed to thwart the best efforts of local medical officers to assert effective control. In such areas, outbreaks continued for many months or years. $^{4}$

A coherent national structure for the containment and control of smallpox in England and Wales had emerged by the late Victorian period. ${ }^{5}$ The development and standardization of vaccination practices in the first half of the nineteenth century had culminated in the Vaccination Act of 1853 and the compulsory vaccination of infants. ${ }^{6}$ While vaccination was a prerequisite for the effective control of smallpox, Anne Hardy observes that uniformly high levels of vaccination coverage were limited by growing public apathy and the emergence of a vigorous anti-vaccination movement that opposed compulsion on political, medical and religious grounds. ${ }^{7}$ Vaccination in infancy did not necessarily afford lifelong immunity to smallpox and, in the absence of compulsory re-vaccination, the Vaccination Acts failed to provide for the long-term protection of the adult population. ${ }^{8}$ Prompted by the resurgence of epidemic smallpox in London in the 1860s, a multifaceted 'stamping out policy' for smallpox control began to gain traction among sanitary departments. ${ }^{9}$ Evolving out of contemporary efforts to control the spread of rinderpest in cattle, the essential elements of stamping out as applied to smallpox included the early detection and notification of cases; the isolation of patients in homes, hospitals or other facilities; the disinfection of their lodgings, clothing, bedding and personal effects; and, in subsequent developments of the method, the 
(re)vaccination of people who had been in contact with cases. ${ }^{10} \mathrm{With}$ the creation of sanitary authorities and the appointment of medical officers of health in urban and rural districts under the Public Health Act (1872), Hardy suggests that:

The establishment in the 1870 s and early 1880 s of a coherent national preventive structure was probably crucial in limiting the opportunities for entry of virulent disease strains, and in raising the efficiency level of local preventive measures. The Infectious Diseases Notification Act of 1899, which made notification compulsory for the infectious diseases, including smallpox, nationally, finally completed this structure. $^{11}$

From thereon, smallpox retreated as a significant cause of mortality in England and Wales. Following the last major epidemic of severe smallpox in 1901-1903, sporadic cases and small outbreaks occurred in conjunction with known or suspected introductions, notably with the return of military personnel from Egypt, Macedonia and elsewhere at the end of the Great War. ${ }^{12}$ As far as the evidence allows, however, smallpox had ceased to be endemic by this time..$^{13}$

The smallpox situation in Britain took an unexpected turn with the appearance and spread of variola minor at the beginning of the 1920s. The aetiological and diagnostic challenges that this typically mild form of smallpox posed to the scientific community are explored by S.R.M. May, who identifies a reassertion of the importance of clinical medicine and epidemiology in disease recognition, management and control at this time. ${ }^{14}$ Although the Ministry of Health described the spread of variola minor as an outstanding epidemiological feature of the 1920s, very little is known of the geographical patterns of epidemic transmission or the reasons why the disease was able to evade the existing machinery for smallpox control in many local government areas of England and Wales. ${ }^{15}$ Against this background, the present paper first examines the challenge posed by variola minor and the geographical course of the national smallpox epidemic of 1920-1935. Then the impediments to effective disease control in areas severely affected by the disease are considered through the lens of the English county of Gloucestershire, a place that is famously and forever associated with smallpox through 
Edward Jenner's pioneering work on vaccination in the late eighteenth century. ${ }^{16}$ Special interest also attaches to Gloucestershire on account of an early and particularly intense smallpox outbreak which, for a time in the spring and summer of 1923, spread out of effective control. ${ }^{17}$ The outbreak garnered much attention in both the popular and medical presses and, as we show, represented a perfect storm of those factors that impeded effective smallpox control in many parts of inter-war Britain. ${ }^{18}$ Above all, our study demonstrates the potential fragility of established disease control systems and the importance of professional and public cooperation - sometimes in the face of vehemently contested evidence over the nature of a disease and the means of its control - in attempts to limit the spread of epidemics.

\section{Smallpox and the Challenge of Variola Minor}

Prior to its global eradication in 1979, person-to-person transmission of variola (smallpox) virus occurred through direct contact with oropharyngeal secretions and, less commonly, through contact with the clothing or bedding of a smallpox patient. ${ }^{19}$ Clinically, the most characteristic feature of the disease was a pustular rash that began to develop two to three weeks after exposure to the virus and which crusted and scabbed three or four weeks later. ${ }^{20}$ Two distinct clinico-epidemiological types of smallpox were recognised in the twentieth century: variola major and variola minor. Variola major was the more severe form of the disease. It was typically associated with a high case-fatality rate (around 30 percent in unvaccinated populations) and, for survivors, its sequelae included severe scarring, blindness and male infertility. Variola minor, on the other hand, was a distinctly milder form of the infection (a case-fatality rate of less than one percent) that was frequently mistaken for chickenpox and other common acute infections. ${ }^{21}$

It was variola minor that spread in epidemic form in England and Wales in 19201935. ${ }^{22}$ Variola minor had first come to notice in South Africa and the USA towards the end of the nineteenth century, with the disease being carried from North America to other parts of the Americas, Europe and the Pacific in the early decades of the twentieth century. ${ }^{23}$ Amongst the first evidence of the disease in Europe was a small outbreak that could be traced back to Salt Lake City which occurred in connection with a Mormon convention in Nottingham, 
England, in $1901 .^{24}$ After the Great War, variola minor was found in certain parts of Western Europe where it was associated with large and geographically widespread epidemics. ${ }^{25}$

Variola minor presented health officers with particular control challenges. ${ }^{26}$ While the disease was susceptible to the same strict control measures as variola major, including vaccination and rapid patient isolation, the characteristic mildness and low mortality rate of variola minor lay at the root of the control problem. ${ }^{27}$ Public indifference to a disease that was all too often perceived as little more than a mild inconvenience, coupled with other public health priorities that vied for scarce resources, sometimes served as impediments to the implementation of effective control measures. Indeed, it is precisely for this reason that the World Health Organization's global smallpox eradication programme encountered difficulties in the late 1970 s. $^{28}$

\section{National Patterns: Epidemic Smallpox in England and Wales, 1920-1935}

The origins of the 1920-1935 epidemic of variola minor in England and Wales are not known with certainty. ${ }^{29}$ Although Sydney Copeman's report of an outbreak in Norfolk and Suffolk during the summer of 1919 marks the usual point of departure for discussions of variola minor in inter-war Britain, its connection (if any) with the ensuing epidemic is unclear. ${ }^{30}$ According to the Ministry of Health, the onset of the epidemic in 1920 was marked by a scattering of 'several small outbreaks' in various counties of northern and southeastern England, of which the events in southwest Essex (59 cases) and Middleton in south Lancashire (79 cases) were deemed to be 'the most serious'. ${ }^{31}$ While each outbreak was 'promptly investigated' and efforts were made to limit the spread of the disease, it would take another 15 years for variola minor finally to be stamped out in England and Wales (Figure 1A). ${ }^{32}$

\section{Data and Methods}

The notification of smallpox cases to the General Register Office (GRO) was a legal requirement in all local government areas of England and Wales at the time of the 1920-1935 epidemic. ${ }^{33}$ To reconstruct the national spread of the epidemic, we draw on smallpox notifications received by the GRO and published in the Registrar-General's Weekly Return. ${ }^{34}$ 
While the Weekly Return contains epidemiological information at the levels of county $(n=62)$ and local government areas $(n=1,930)$, county-level data were selected as the most appropriate scale on which to capture regional trends in recorded disease activity. ${ }^{35}$ For each county of England and Wales disease counts were abstracted from the Weekly Return to yield 62 (counties) $\times 16$ (years) matrices of smallpox notifications and rates per 100,000 population. These matrices form the basis of all analysis in the present section. For reference, Table 1 gives the number of smallpox notifications and the average annual rate per 100,000 population in those counties with the highest recorded disease incidences $(>1,000$ notifications) for the period 1920-1935.

\section{Location quotients}

To reconstruct the geographical course of the national epidemic, annual smallpox notification rates in each of the 62 counties were indexed to the corresponding national rate using location quotients. ${ }^{36}$ Analytical details are given in Appendix 1 but, as applied here, the location quotient $(L Q)$ provides a (scaled) measure of the intensity of smallpox activity in a given county relative to England and Wales as a whole. A value of unity $\left(L Q_{i t}=1.00\right)$ signifies an equivalence of disease rates at the county and national levels, while higher and lower values signify county-level epidemics that were more intense $\left(L Q_{i t}>1.00\right)$ or less intense $\left(L Q_{i t}<\right.$ 1.00) than the national epidemic. The subscripts, $i$ and $t$, index the $i$-th county in year $t$.

\section{Epidemic centroids}

To supplement the location quotient analysis, county-level smallpox notifications were used to estimate the mean geographical centre, or centroid, of reported disease incidence in each epidemic year. ${ }^{37}$ Again, technical details are given in Appendix 1, but centroids allow the spatial trend in epidemic transmission to be tracked over time.

\section{National Spread Reconstructions}

The maps in Figures 2 and 3 are based on location quotients and identify those counties in which the smallpox notification rate exceeded the national rate $\left(L Q_{i t}>1.00\right)$ in each year of the build-up (1920-1927; Figure 2) and fade-out (1928-1935; Figure 3) phases of the epidemic. Epidemic phases are defined relative to the peak in the national epidemic curve (Figure 1A), 
with a burgeoning (build-up, 1920-1927) and waning (fade-out, 1928-1935) of annual notifications respectively. The maps show three levels of disease intensity, with the most intense category $\left(L Q_{i t} \geq 5.01\right)$ identifying counties with smallpox rates that were more than five times the corresponding national rate. For reference, Table 1 gives the major periods of smallpox activity in high incidence ( $>1,000$ notified smallpox cases) counties. We consider the build-up and fade-out phases in turn.

Epidemic build-up (1920-1927)

A prominent feature of this phase was the primary focus of disease activity in central and northern counties of England. Much of southern England and most of Wales, by contrast, remained 'comparatively free' of the disease throughout this period. ${ }^{38}$ Following the initial outbreaks in 1920, a persistent core of high case-intensity counties in central (Derbyshire and Nottinghamshire) and northern (Yorkshire) England emerged in 1921, around which much of the subsequent build-up phase of the epidemic unfolded (Figures 2B-H; Table 1). In the northeast, Northumberland and Durham emerged as persistent centres of intense smallpox activity from 1924-1925 (Figures 2E-H; Table 1). At the same time, the disease extended southwards and eastwards from Derbyshire and Nottinghamshire into adjacent areas of north Leicestershire (Ashby Woulds and Melton Mowbray), west Lincolnshire (Gainsborough and Sleaford) and Northamptonshire (Kettering). ${ }^{39}$

Away from the core areas of smallpox activity in central and northern England, two additional foci of disease activity merit special mention. First, Figures 2D and E identify Gloucestershire as a southern outlier of higher than national incidence in the relatively early stages (1923-1924) of the epidemic. Second, Figure 2H shows the delayed appearance of smallpox in the South Wales coalfield. The mining towns of Monmouthshire were reached in February and March 1927, with the disease spilling over into neighbouring areas of Brecknockshire in the following weeks and months. ${ }^{40}$

Epidemic fade-out (1928-1935)

As the epidemic began to wane in the core areas of central and northern England, the disease began to affect more southerly counties. Leicestershire, which had experienced a flare-up in 
1924-1925, became a persistent centre of intense smallpox activity in 1929-1932 (Figures 3BE; Table 1). Proximal counties of the South Midlands, including Northamptonshire and Bedfordshire, also recorded high incidences at this time. Further south, the disease began to spread with some force in London from 1929 (Figure 3B-G; Table 1), possibly associated with an introduction of variola virus by vagrants from infected areas to the north of the metropolis. ${ }^{41}$ Essex also experienced a protracted increase from 1929 (Figure 3B-F; Table 1), while prominent disease outbreaks were also recorded in Wiltshire (Figure 3B), East Sussex (Figure 3E) and Surrey (Figure 3F). The last smallpox case was traced to Norfolk in 1935 (Figure 3H), marking the end of a sixteen year chain of disease transmission.

\section{Disease Centroids}

The disease centroids in Figure 4 capture the north-south shift in the geographical focus of smallpox activity as the epidemic evolved. During the build-up phase (1920-1927), the dominant trend was for the centroid to drift northwards, along the spine of England, from a position close to the southern border of Derbyshire and Nottinghamshire (1920) to a northernmost point in the North Riding of Yorkshire (1926). As the epidemic began to wane (1928-1935), however, the centroid began an accelerated shift southwards into north Derbyshire (1928), central Leicestershire (1929) and then below the Severn-Wash line. London and the southeast were reached in 1930-1934, before the final termination in Norfolk (1935).

\section{The Gloucestershire Smallpox Anomaly, 1923-1924}

Gloucestershire (Figure 5) represented a southern anomaly in the build-up phase. ${ }^{42}$ Notwithstanding the relative distance of the county from the principal foci of disease activity in central and northern England, smallpox began to spread there in the spring of 1923 (Figure 1B). By the end of that year, the county's smallpox notification rate $(121.39$ per 100,000 population) exceeded the corresponding national rate $(6.44$ per 100,000) by a factor of 19 $(L Q=18.85$; see Figure 2D). In this section, we explore the course of the Gloucestershire outbreak and the apparent reasons for the intense spread of the disease at the time. 


\section{Data and Methods}

Our investigation adopts a mixed methods approach that exploits the complementary nature of the available epidemiological evidence. ${ }^{43}$ By combining the statistical record of smallpox notifications in the shire with local documentary records, our approach seeks to shed light on particular local social and geographical contexts that impeded efforts to control the national epidemic.

\section{Data sources}

(1) Quantitative data: smallpox notifications. As with our national-level analysis, we draw on the official notifications of smallpox included in the Registrar-General's Weekly Return. At the time of the Gloucestershire outbreak, the county was divided into thirty-seven local government areas (county boroughs, municipal boroughs and urban and rural districts). For each of these areas, disease counts were abstracted from the Weekly Returns to yield a 105week series of notifications, January 1923-December 1924. Summary information on the population size and the number of notifications in the set of areas under investigation is given in Table 2.

(2) Qualitative data: Gloucestershire Archives. To examine the circumstances underpinning smallpox transmission in Gloucestershire we draw on the contemporary documentary records held by Gloucestershire Archives. ${ }^{44}$ Much of the public archive is electronically catalogued, and an exhaustive search of this resource yielded a wide range of official materials relating to the 1923-1924 outbreak in the fonds of Gloucestershire County Council, Gloucester City Council, East Dean and Lydney Rural District Councils and other official bodies, societies and organisations. ${ }^{45}$

\section{Origin and Course of the Gloucestershire Outbreak}

The first known cases of smallpox can be traced to early and mid March $1923 .{ }^{46}$ The medical officer of health for Cheltenham Town (Cheltenham MB) observed several patients at this time and attempts to determine the source(s) of infection in these and other cases resulted in the detection of small foci of smallpox in various parts of the county, some of which were connected with putative cases of chickenpox in Gloucester City (Gloucester CB). ${ }^{47}$ Allowing 
for reporting delays that accompanied the investigation of these early cases, the first notified cases were included in the Registrar-General's Weekly Returns for the week ending 14 April 1923. From thereon the Returns provide a continuous record of notifications until the week ending 24 May 1924 (Figure 6).

Table 2 and Figure 6 summarise the course of the outbreak. There are two defining features. First, it was spatially focussed on just two local government areas, Gloucester CB and East Dean and United Parishes RD. Together, these two accounted for 952 (89 percent) of the 1,070 notified cases. Although other areas (Cheltenham MB, Gloucester RD and Stroud RD) experienced limited flare-ups in the outbreak's early stages, most parts of the county recorded little or no evidence ( $<10$ cases) of smallpox. Second, the disease spread in the principally affected areas as two temporally distinct waves of infection: a primary Wave I in Gloucester CB (April-November 1923) with a high peak in midsummer; and a secondary Wave II in East Dean and United Parishes RD (September 1923-May 1924), with a peak in early winter. While there is no direct evidence regarding the source(s) of infection to spark Wave II, the proximity of East Dean and United Parishes RD to Gloucester CB suggests that the latter may have played some role in the initiation of this wave of infection. ${ }^{48}$

\section{Impediments to Effective Disease Control}

Why did Wave I of the outbreak spread so rapidly and extensively in Gloucester CB, and what were the impediments to effective disease control in the two main foci of smallpox activity? A wide range of contributory factors challenged the successful implementation of the established practice of 'stamping out' as a means of smallpox outbreak control. These included vaccination levels, clinical case recognition and misdiagnosis, the lack of isolation hospitals, divisions and tensions between medical officers, and public perception and response. All featured prominently in the viewpoints and perspectives of local actors and the organisations to which they were attached. We consider each in turn.

\section{Vaccination levels}

Gloucester City and vicinity was a prominent centre of resistance to vaccination in the late nineteenth century. ${ }^{49}$ Kept alive in the writings and oratory of Dr Walter Hadwen, a Gloucester 
general practitioner and a prominent anti-vaccination campaigner, this popular spirit of resistance continued well into the $1920 \mathrm{~s} .{ }^{50}$ Of those Gloucestershire children who were four or five years old at the time of onset of the local epidemic, only 20 percent or so had been successfully vaccinated in infancy. ${ }^{51}$ This level was somewhat higher than in some other centres of resistance to vaccination (the equivalent figure for Leicestershire, for example, was just 8 percent), but it was substantially below the national level of 41 percent. ${ }^{52}$ Perhaps unsurprisingly, therefore, some contemporaries placed emphasis on the role of anti-vaccination sentiment in the development of the 1923-1924 outbreak, with vaccination being deemed an 'anathema to so many' of the local population. ${ }^{53}$ Only 'a very small proportion' of children born in Gloucester City in the years preceding the outbreak had been vaccinated against smallpox, with 'nearly all persons of the Working Classes' claiming exemption. ${ }^{54}$ Recognising the particular risks of disease transmission among a large body of susceptible children, Gloucester County Council's Higher Education Sub-Committee resolved on 16 June 1923 that school governors should be invited 'to consider the desirability of requiring children who are unvaccinated to be excluded' ${ }^{55}$ Notices promoting the uptake of vaccination were placed in the Gloucester Chronicle and various other public places but, in the absence of the widespread adoption of vaccination, a Special Health Sub-Committee of Gloucester City Council was informed on 29 June that it was 'impossible to say when the epidemic would terminate' ${ }^{56}$

\section{Clinical case recognition and misdiagnosis}

The clinical case recognition of variola minor was a common problem for local authorities and the epidemic prompted an extensive medical debate on the differential diagnosis of smallpox and chickenpox in England and Wales. ${ }^{57}$ It soon became apparent that the misdiagnosis of variola minor as chickenpox was an integral feature of the early stages of the Gloucester outbreak. Investigations revealed over a hundred such misdiagnoses in the period to 11 June 1923, and many more cases came to light in the following days and weeks. ${ }^{58}$ Two reasons for such a large number of errant diagnoses can be identified, the first 'owing to the mildness of most cases' and the second owing to Gloucester's medical officer of health, Dr James R. Bibby, who steadfastly refused to accept the disease's true form and who 'diagnosed all of the early 
cases as being chickenpox' ${ }^{59}$ Indeed, Bibby was roundly condemned for his actions, which were described by one prominent local observer, Maynard Colchester-Wemyss, as 'a sad state of affairs ... created by the incompetence of one man'. ${ }^{60}$ The consequence was simple: the usual procedure for the rapid isolation of smallpox patients was not adopted in many instances, and large numbers of infectious cases were permitted to circulate freely and shed virus in the community. In October 1923, when the epidemic in Gloucester was finally in retreat, a letter from the Ministry of Health served to remind city councillors that the serious state of affairs had arisen, at least in part, 'through the failure to recognise earlier the nature of the epidemic' ${ }^{61}$

\section{Isolation hospitals}

Even when cases of smallpox were correctly diagnosed, the local authorities were confronted with the vexed issue of isolation facilities for the patients. The Gloucestershire smallpox epidemic of 1896 and the riot that accompanied the opening of Oakridge isolation hospital, Stroud, may have cast a long shadow over the matter. ${ }^{62}$ While home quarantine was utilised as a temporary measure in the early months of 1923, members of Gloucester City Council noted that 'the greatest obstacle encountered [to effective disease control] was the absence of adequate hospital accommodation for the removal and isolation of every infected person' ${ }^{63}$ The existing smallpox hospital at Longford had just eighteen beds and, as an emergency measure, an aerodrome at Brockworth was converted into a temporary smallpox hospital (Figure 5C). ${ }^{64}$ Although resources were hastily marshalled, and the Brockworth hospital was ready to receive patients at 6:00 pm on Friday 15 June 1923, it is evident from Figure 6 that the Gloucester outbreak was already well advanced by that stage. ${ }^{65}$ In short, the local authorities were unprepared for the effective isolation of patients in an outbreak of the magnitude seen in 1923.

\section{Medical officers: divisions and tensions}

We have already noted the issue of habitual case misdiagnosis by Gloucester's medical officer of health, Dr James Bibby. As medical officer of health, Bibby was responsible for maintaining the local register of infectious diseases. It was in this capacity that, between January and May 1923, '33 cases were notified by eight different Medical men of the City as "Small-pox" or 
"Query Small-pox", but were entered [in the register] ... as Chicken-pox'.66 This miscommunication, or perhaps Bibby's refusal to accept the original diagnoses, led to tensions between medical professionals in the city. As a remedial measure, Dr W.H. Davison was drafted in from Birmingham on 11 June to take temporary charge of the outbreak response. ${ }^{67}$ The efficacy of Davison's work, however, appears to have been compromised by an apparent failure of health personnel to ensure the timely removal of smallpox patients to hospital, and by the unauthorised discharge of patients from hospital. ${ }^{68}$ Davison's frustrations became apparent when he drew attention to 'certain influences' that were endeavouring to 'throw sand on the administrative machinery designed to protect the community' and that 'it was a ridiculous position to have in charge of Smallpox cases a Medical Superintendent who did not admit the cases to be Smallpox' ${ }^{69}$ Davison threatened to resign on 27 June, but was persuaded to remain in post by Gloucester City Council. ${ }^{70}$ At about the same time, Bibby was relieved of all duties in relation to the control of smallpox. He tendered his resignation as medical officer of health for Gloucester a few days later, declaring his intention to stand as a candidate in the upcoming city council elections. ${ }^{71}$ In the event, Bibby was returned unopposed as the Labour Party councillor for the city's Southend Ward on Thursday 1 November, having used the political fallout from the smallpox epidemic as a platform for his own campaign and as a means of rallying support for fellow Labour Party candidates in several other wards. ${ }^{72}$ Although Bibby's stance on vaccination is unclear, he was joined on more than one occasion in his electioneering by a 'staunch friend' the prominent local anti-vaccination campaigner, $\mathrm{Dr}$ Walter Hadwen. ${ }^{73}$

\section{Public perception and response}

Public involvement in the development of the epidemic was not limited to a prevailing resistance to vaccination. Gloucester City Council highlighted concerns that 'the people as a whole are not treating this epidemic seriously' and that the public did 'not believe that Smallpox can exist in a very mild form' ${ }^{74}$ Some smallpox patients (or their guardians) refused to give consent for admission to isolation facilities and, in such instances, a Magistrate's Order had to be obtained for removal to hospital. ${ }^{75}$ Cases of wilful obstruction and violent resistance 
were sometimes encountered, as in the instance of a father who 'picked up a poker and had to be restrained by other members of the family' when attempts were made to remove his young child to hospital. ${ }^{76}$ In other instances, cases of smallpox were simply concealed from the view of the authorities. ${ }^{77}$ Both of these public opposition scenarios served to increase the difficulties of implementing effective disease control measures.

\section{Other factors}

Contemporary observers identified a range of other factors that may have, directly or indirectly, influenced the incidence of smallpox in the 1923-1924 outbreak. These included the lack of a properly equipped steam disinfector for the purging of infected properties; the socioeconomic conditions engendered by high levels of unemployment that were twice the national average; and the role of public facilities and services, including schools and libraries, in the spread of the disease. ${ }^{78}$

\section{Discussion}

The variola minor epidemic of 1920-1935 marked the last occurrence of smallpox as an endemically-transmitted infection in the British Isles. ${ }^{79}$ It is also a prime example of a smallpox epidemic that spread out of effective control in a national population with waning levels of vaccine-induced immunity. ${ }^{80}$ At the national level, our analysis has demonstrated that the build-up phase of the epidemic was characterised by the establishment of persistent areas of high disease incidence in central (Derbyshire and Nottinghamshire) and northern (Durham, Northumberland and Yorkshire) England (Figure 2). Elsewhere, we have demonstrated that these high incidence areas were statistically associated with mining communities attached to the Nottinghamshire-Derbyshire and Durham-Northumberland coalfields. ${ }^{81}$ As the epidemic began to wane in the late 1920s, there was a rapid north-south shift in the centre of disease activity to London and the south-east where the epidemic remained focused until the mid-1930s (Figures 3 and 4). Although the underpinning mechanisms of the epidemic decline are uncertain, Sir George Newman, Chief Medical Officer, speculated that 'some degree of herd immunity' may have driven the geographical and magnitudinal retreat of the disease at this time. ${ }^{82}$ Whatever the contributing factors, the last notified case of variola minor was traced to 
the King's Lynn area of Norfolk in 1935, thereby marking the end of sustained variola transmission in Britain. ${ }^{83}$

The County of Gloucestershire represents a southern anomaly in the generalised pattern of epidemic expansion in Figure 2. This anomalous area developed in association with the highlevel transmission of variola minor in just two local government areas, Gloucester CB and East Dean and United Parishes RD (Table 2). Here, the disease spread as sequenced waves of infection, with a primary wave centred on Gloucester City and a secondary wave centred on East Dean (Figure 6). ${ }^{84}$ Foremost among the factors which allowed these waves to develop was the low uptake of vaccination by the population. A deep-seated anti-vaccination sentiment in Gloucester certainly played a role in this matter, as it did in other centres - such as Leicester with a tradition of resistance to vaccination. ${ }^{85}$ Yet, the main epidemic wave of smallpox appeared much earlier (and spread more intensely) in Gloucester CB than in Leicester CB, suggesting that anti-vaccination sentiment alone could not account for the events in the former place. It is also the case that the low levels of vaccination uptake in Gloucester reflected a more general neglect of vaccination that pervaded much of England and Wales at the time. ${ }^{86}$ In the index year of the epidemic, 1920, fewer than 40 percent of infants in England and Wales were protected against smallpox and this came on a declining curve of infant vaccination rates (Figure 1A). ${ }^{87}$ Although the onset of the epidemic served as a fillip to vaccination, especially among the very young, the effect was relatively brief and some local authorities struggled in their efforts to convince the public of the importance of prophylaxis. ${ }^{88}$ Writing in his Annual Report for 1926, Sir George Newman left the public in no doubt about his position on the matter:

It must be said, quite plainly, that the ... English people must make up their minds whether they prefer smallpox or vaccination ... [A]s I said quite explicitly in my official reports for 1924 and 1925, the immediate duty in the presence of an epidemic is vaccination. ${ }^{89}$

Opposition and antipathy to vaccination were not, however, the sole impediments to effective smallpox control in Gloucestershire. Additional factors assumed prominence, many 
of which were echoed in the experiences of other high-incidence areas of England and Wales. Clinical case recognition, in particular, was a more or less universal problem as illustrated by numerous reports of the misdiagnosis of variola minor as chickenpox in Nottingham, Preston, Durham and elsewhere. ${ }^{90}$ The difficulties of differential diagnosis were exacerbated by the lack of familiarity of many diagnosing physicians with smallpox. ${ }^{91}$ Recognising the seriousness of the situation, a substantial number of local authorities took the unusual step of adding chickenpox to the list of diseases subject to mandatory notification with a view to ensuring early medical intervention. ${ }^{92}$ But, even when cases of smallpox were correctly identified, the experience of Gloucestershire exemplifies the general lack of hospital provision, with attendant consequences for the prompt removal and isolation of patients, in many local authority areas of England and Wales. ${ }^{93}$ Nor was Gloucestershire alone in the public's wilful obstruction of health officers in the execution of their duties, with case concealment being the most prevalent issue nationwide. ${ }^{94}$

The official response to the smallpox outbreak in the City of Gloucester was characterised by professional divisions and tensions that culminated in the resignation of the medical officer of health, Dr James R. Bibby, at the end of June 1923. It would seem that similarly 'ill-administered' health departments were encountered elsewhere. ${ }^{95}$ The medical officers of health for two such departments in northeast England were relieved of their positions in the course of the epidemic, while the part-time medical officer of health for Ashington UD, Northumberland, was singled out for his failure to adopt 'effective measures to limit the spread of infection' even when assistance in such matters was offered by the County Health Department. ${ }^{96}$ It is perhaps noteworthy that such failings came at a time when the civil health services were still recovering from the disruption engendered by the Great War and when, in the words of the Ministry of Health, public health work had 'become more and more a distinct branch of the medical profession calling for specialised training and experience' ${ }^{97}$ Fortunately, failings of the type seen in Gloucester and Ashington were rarely recorded and may be deemed to be uncharacteristic of the national picture.

The analysis we have presented is subject to the limitations of the available data. We have already noted that case misrecognition, misdiagnosis and concealment were ubiquitous 
issues and these represent potential sources of error in the statistical records of the RegistrarGeneral. Similarly, it is likely that some people endured a mild bout of variola infection without ever seeking the assistance of medical personnel and were thereby excluded from the official record. ${ }^{98}$ As regards the documentary evidence from the Gloucestershire Archives, the fragmentary nature of some archival materials and their primary focus on the official records of local councils may have engendered biases in the analysis presented. ${ }^{99}$ Our results should be interpreted with these limitations in mind.

In their investigations of the 1918-1919 'Spanish' influenza epidemic in the United States, Howard Markel, Alexandra Stern and colleagues sifted the evidence to determine those (non-pharmaceutical) interventions that limited the spread of the disease in particular localities and communities. ${ }^{100} \mathrm{With}$ a similar focus on local intervention strategies, the present study has sought to identify the circumstances under which established protocols for the epidemic control of smallpox failed in some local government areas in inter-war England and Wales. A theme that emerges from the influenza studies of Markel et al., and which comes to the fore in the present study, is the importance of professional and public cooperation in any effective public health response. ${ }^{101}$ Above all, the Gloucestershire example demonstrates the potential fragility of established disease control systems and how a signal failure of cooperation among public health professionals, in an area with a tradition of public opposition to vaccination, contributed to the widespread dissemination of variola minor.

The global eradication of smallpox in 1979 was one of the landmark events of twentieth-century public health medicine. The feat came 180 or so years after Jenner had provided the primary tool (vaccination) to achieve the goal. ${ }^{102}$ Vaccination was a necessary but not sufficient - condition for eradication, and a combination of mass vaccination and the 'stamping out' system of smallpox control that had developed in late nineteenth-century Britain became the basis of the World Health Organization's eradication strategy in the 1960s and 1970s. ${ }^{103}$ The road to eradication was slowed by a gamut of logistical, socio-cultural and geographical factors. Key among these was a belief, or otherwise, in the safety and efficacy of smallpox vaccine. ${ }^{104}$ Today, in an era which generally accepts mass vaccination as a tool for communicable disease control, it is sometimes hard to understand how personal views could 
and did fly in the face of the apparent scientific evidence. ${ }^{105}$ But the same phenomenon has been seen in recent decades among those who oppose vaccination on religious, political and safety grounds. ${ }^{106}$ The adverse publicity surrounding the safety of the measles, mumps and rubella (MMR) vaccine in Britain during the 1990s, with an associated loss of public confidence in the vaccine, is a prominent case in point. ${ }^{107}$ So it was that opposition to vaccination, combined with public apathy and the disagreements of medical men over the nature and control of variola minor, all contributed to the spread of the last major epidemic of smallpox in the British Isles. As an object lesson in the need to tailor infectious disease control strategies to particular people and places, the late Cyril Dixon, Professor of Preventive and Social Medicine and a biographer of smallpox, noted how the experience of smallpox in Gloucester '...emphasizes the need in the practice of public health for the development and use of skills in the assessment of the character or personality of a town, and its probable reactions to outbreaks of a disease such as smallpox, and to plan control measures accordingly'. ${ }^{108}$ 


\section{Appendix 1: National Epidemic Patterns}

This appendix outlines the methods that underpin the analysis of national spread patterns in Figures 2-4.

\section{Location quotients (Figures 2 and 3)}

In general terms, the location quotient $(L Q)$ is an index for comparing the concentration of a particular phenomenon in a given geographical area $i$ with some reference area $j .{ }^{109}$ For the purposes of the present analysis, the location quotient $L Q_{i t}$ for county $i(=1,2, \ldots, 62)$ and annual period $t(=1920, \ldots, 1935)$ was defined as

$$
L Q_{i t}=r_{i t} / R_{t} \text {, }
$$

where $r_{i t}$ and $R_{t}$ are, respectively, the county- and national- (England and Wales) level smallpox notification rates per 100,000 population. Values of $L Q_{i t}>1.00$ signify a higher notification rate in county $i$ (that is, more intense smallpox activity) as compared to the national level $j$, while values of $L Q_{i t}<1.00$ signify a lower notification rate. Adopting this method, Figures 2 and 3 shade those counties in which the smallpox notification rate exceeded the national rate (that is, $\left.L Q_{i t}>1.00\right)$ in each year of the build-up (1920-1927; Figure 2) and fadeout (1928-1935; Figure 3) phases of the epidemic.

\section{Epidemic centroids (Figure 4)}

Following Cliff and colleagues, let $\bar{u}_{i}$ represent the horizontal Cartesian coordinate of the geographical centroid of the $i$ th county and let $\bar{v}_{i}$ represent the vertical coordinate. ${ }^{110}$ In addition, let the notified number of smallpox cases for the $i$ th county be $I_{i t}$. The mean geographical centre of smallpox incidence for the set of 62 counties in annual period $t$ is then located at $\bar{U}_{t}, \bar{V}_{t}$, where

$$
\bar{U}_{t}=\sum_{i=1}^{62} I_{i t} u_{i} / \sum_{i=1}^{62} I_{i t}
$$

and 


$$
\bar{V}_{t}=\sum_{i=1}^{62} I_{i t} v_{i} / \sum_{i=1}^{62} I_{i t}
$$

Annual positions of the mean geographical centre of smallpox incidence are plotted in Figure 4. 


\section{Acknowledgements}

The authors are grateful to the anonymous referees and the Editor for their helpful comments on an earlier draft of this article. The authors are also grateful to the staff of the Gloucestershire Archives and the Library of the London School of Hygiene and Tropical Medicine for their assistance in accessing the archival and statistical materials used in this research. 
Table 1. Smallpox: high incidence counties (>1,000 notifications) of England and Wales, 1920-1935.

\begin{tabular}{lrll}
\hline & Smallpox notifications, & \\
County & $1920-35^{1}$ & Epidemic period $^{2}$ \\
\hline Durham & $17,783(73.94)$ & $1925-1929$ \\
London & $10,852(15.48)$ & $1929-1934$ \\
Yorkshire, West Riding & $10,597(19.55)$ & $1921-1923,1926-1929$ \\
Derbyshire & $6,709(55.93)$ & $1921-1929,1931$ \\
Leicestershire & $5,032(59.42)$ & $1924-1925,1929-1932$ \\
Essex & $4,479(17.30)$ & $1920,1929-1933$ \\
Monmouthshire & $4,167(57.73)$ & $1927-1930,1934$ \\
Northumberland & $3,407(28.23)$ & $1924-1929,1932$ \\
Nottinghamshire & $3,112(28.36)$ & $1921-1928$ \\
Lancashire & $2,730(3.40)$ & 1920,1934 \\
Glamorganshire & $2,493(12.33)$ & $1928-1929,1931$ \\
Yorkshire, North Riding & $2,356(32.04)$ & $1920-1925,1927-1928$ \\
Staffordshire & $1,543(6.78)$ & $1928-1929$ \\
Gloucestershire & $1,187(9.46)$ & $1923-1924$ \\
England and Wales & $81,983(13.14)$ & -- \\
\hline
\end{tabular}

Notes: ${ }^{1}$ Average annual notification rate per 100,000 population in parentheses. ${ }^{2}$ Defined as years in which the county notification rate exceeded the national notification rate (i.e. $L Q_{i t}>$ 1.00); see Figures 2 and 3. 
Table 2. Smallpox notifications in the local government areas of Gloucestershire, 1923-1924.

\begin{tabular}{|c|c|c|c|c|c|c|c|}
\hline \multirow[b]{2}{*}{ Local government area ${ }^{1}$} & \multirow[b]{2}{*}{$\begin{array}{c}\text { Population } \\
\qquad(1921)^{3}\end{array}$} & \multicolumn{6}{|c|}{ Smallpox notifications (quarter-year) ${ }^{2}$} \\
\hline & & $\begin{array}{c}1923 \\
\text { (Apr.-Jun.) }\end{array}$ & $\begin{array}{c}1923 \\
\text { (Jul.-Sept.) }\end{array}$ & $\begin{array}{c}1923 \\
\text { (Oct.-Dec.) }\end{array}$ & $\begin{array}{c}1924 \\
\text { (Jan.-Mar.) }\end{array}$ & $\begin{array}{c}1924 \\
\text { (Apr.-Jun.) }\end{array}$ & Total \\
\hline Gloucester CB & 51,330 & $247(481.2)$ & $346(674.1)$ & $45(87.7)$ & $13(25.3)$ & $4(7.8)$ & $655(1,276.1)$ \\
\hline East Dean and United Parishes RD & 20,486 & $8(39.1)$ & $26(126.9)$ & $137(668.7)$ & $107(522.3)$ & $19(92.7)$ & $297(1,449.8)$ \\
\hline Cheltenham MB & 48,430 & $27(55.8)$ & $3(6.2)$ & $1(2.1)$ & $0(0.0)$ & $0(0.0)$ & $31(64.0)$ \\
\hline Stroud RD & 28,682 & $27(94.1)$ & $2(7.0)$ & $0(0.0)$ & $0(0.0)$ & $0(0.0)$ & $29(101.1)$ \\
\hline Gloucester RD & 13,113 & $14(106.8)$ & $7(53.4)$ & $2(15.3)$ & $0(0.0)$ & $0(0.0)$ & $23(175.4)$ \\
\hline Other areas $(n=32)$ & 595,610 & $24(4.0)$ & $11(1.8)$ & $0(0.0)$ & $0(0.0)$ & $0(0.0)$ & $35(5.9)$ \\
\hline Total & 757,651 & 347 (45.8) & 395 & 185 & 120 & $23(3.0)$ & $1,070(141.2)$ \\
\hline
\end{tabular}

Notes: ${ }^{1}$ See Figure 5 for locations. ${ }^{2}$ Rate per 100,000 population in parentheses. ${ }^{3}$ Estimates from Census Office, Census of England and Wales 1921. County of Gloucester, London, 1923. 
A England \& Wales (1911-1945)
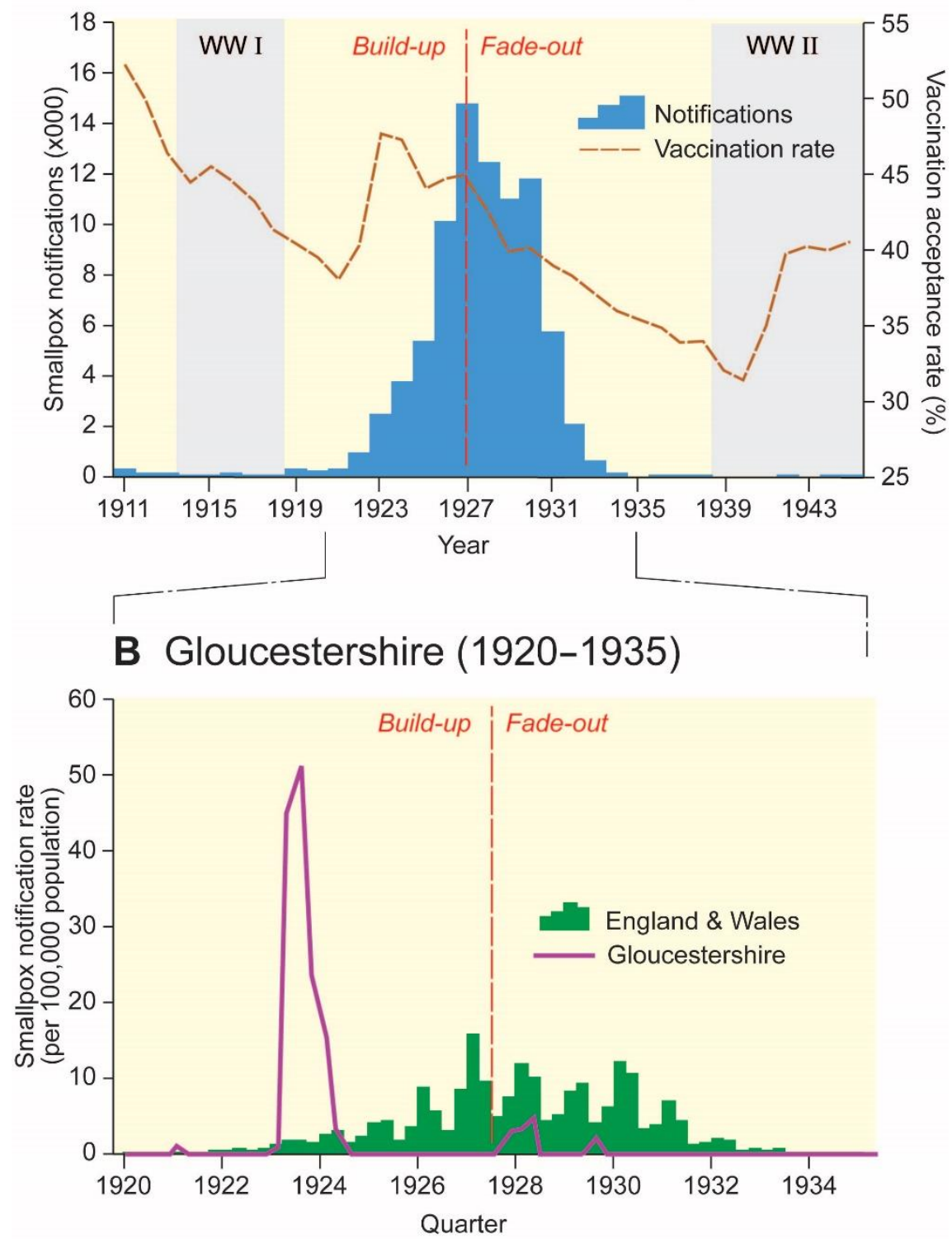

Figure 1. Epidemic smallpox in England and Wales. (A) Annual series of smallpox notifications in England and Wales, 1911-1945. The broken line trace plots, by birth registration year, the percentage proportion of infants who were vaccinated against smallpox in England and Wales. (B) Quarterly series of smallpox notification rates per 100,000 population for the county of Gloucestershire (line trace) and England and Wales (bar chart), 1920-1935. Graphs drawn from data in: Fenner, Henderson, Arita, Ježek and Ladnyi, Smallpox and its Eradication, 325; Local Government Board, Forty-eighth Annual Report, 207; Ministry of Health, Annual Report of the Ministry of Health; Registrar-General for England and Wales, Weekly Return of Notifications. 


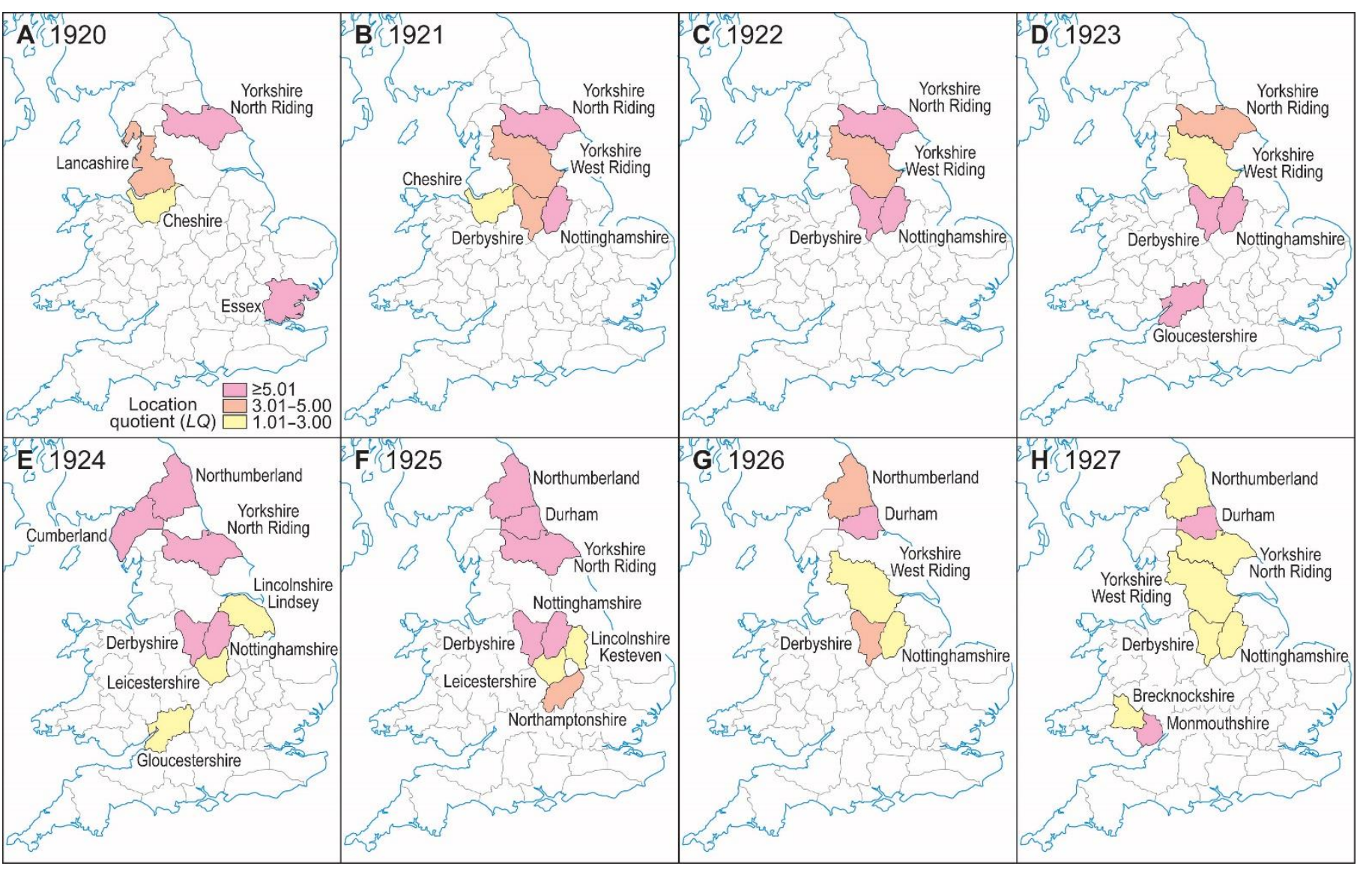

Figure 2. Geographical spread of the variola minor epidemic in England and Wales, I: epidemic build-up (1920-1927). The maps are based on location quotients $(L Q)$ and shade counties with smallpox notification rates per 100,000 population that, for a given year, were in excess of the corresponding national rate $\left(L Q_{i t}>1.00\right)$. Location quotients are mapped at three levels of intensity; the highest level $\left(L Q_{i t} \geq 5.01\right)$ defines counties with smallpox rates in excess of five times the corresponding national rate. 

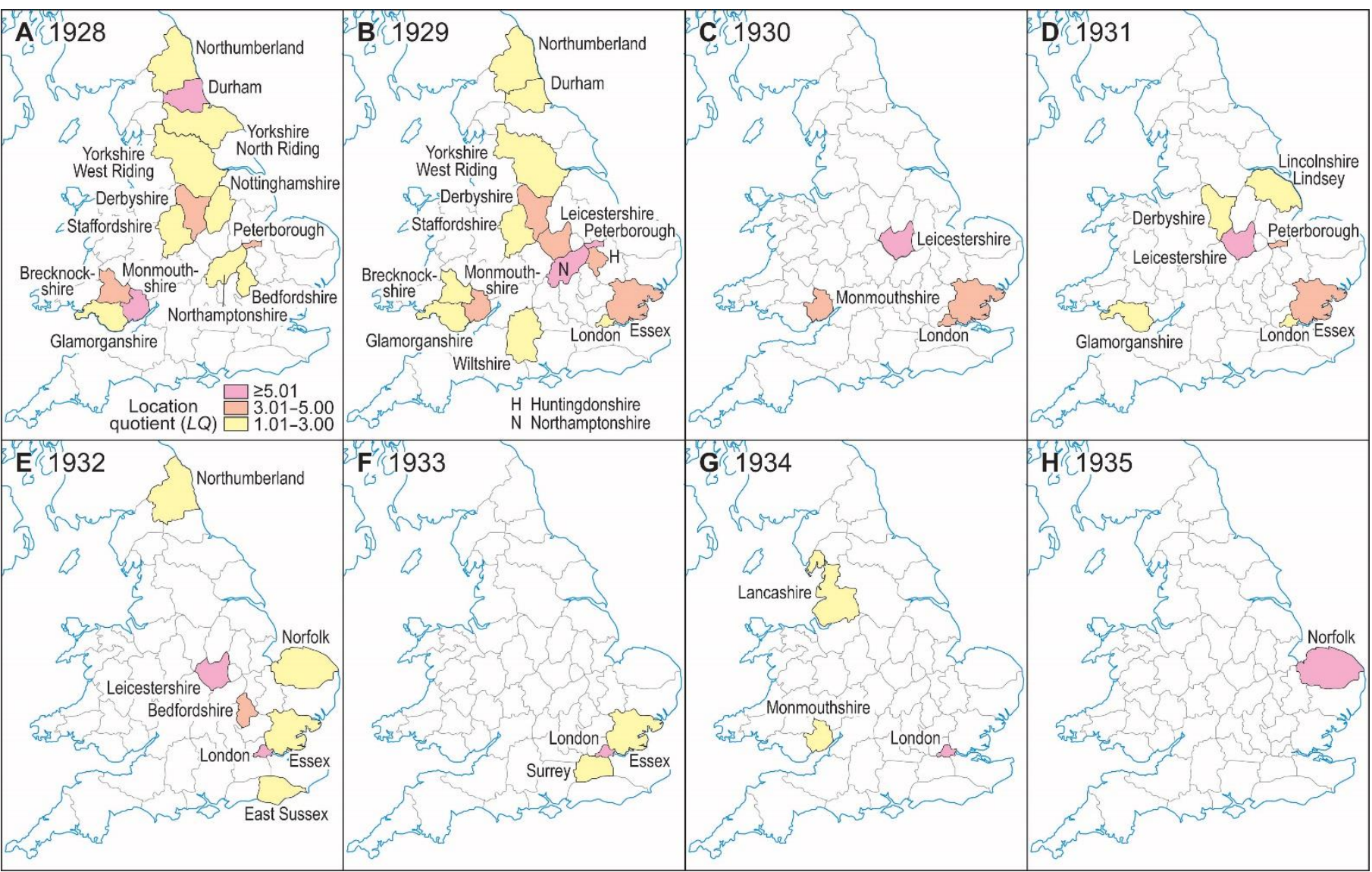

Figure 3. Geographical spread of the variola minor epidemic in England and Wales, II: epidemic fade-out (1928-1935). Mapping conventions are provided in the caption to Figure 2. 


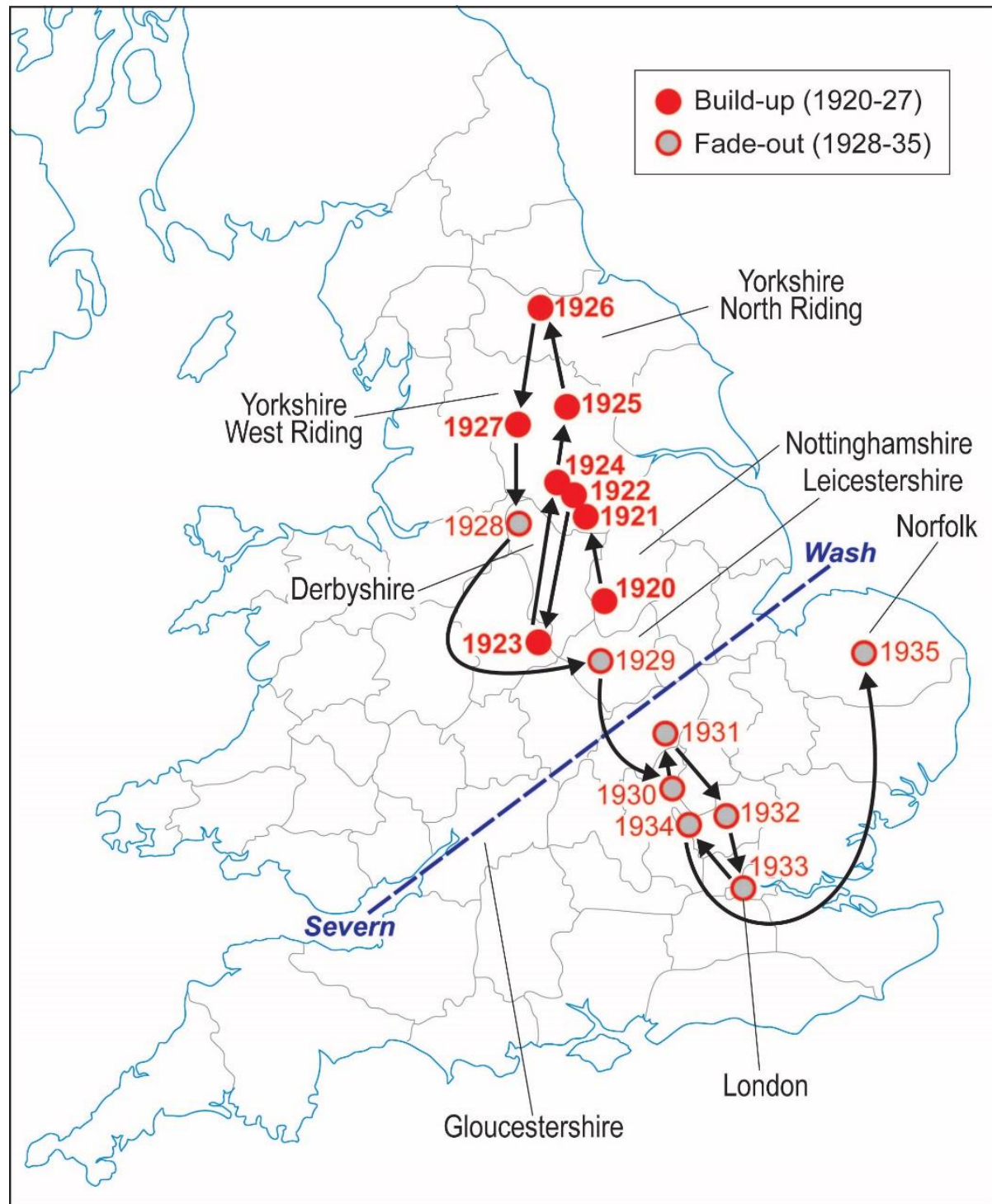

Figure 4. Epidemic centroids for variola minor notifications in the counties of England and Wales, 1920-1935. 

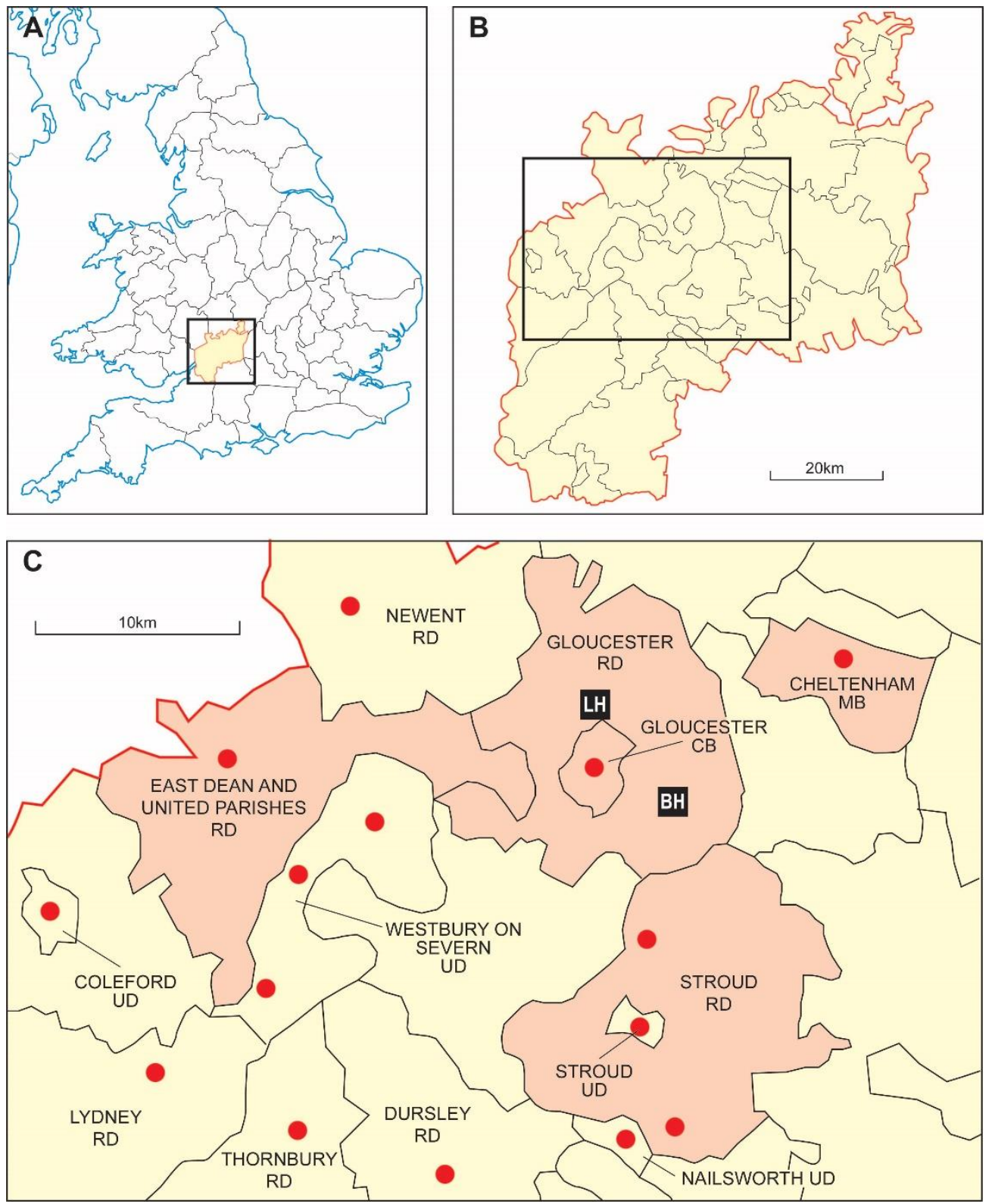

Figure 5. (A) Gloucestershire. (B) Local government areas of Gloucestershire $(n=37)$. (C) Local government areas that notified cases of smallpox; the principal centres of smallpox notifications (>10 cases) are highlighted. Summary details of smallpox notifications are provided in Table 2. The locations of Longford Smallpox Hospital (LH) and the temporary smallpox hospital at Brockworth $(\mathrm{BH})$ are shown. $\mathrm{CB}$, county borough; $\mathrm{MB}$, municipal borough; RD, rural district; UD, urban district. Source: boundaries in maps (B) and (C) drawn from Great Britain Historical GIS Project and the University of Portsmouth, A Vision of Britain Through Time, $\quad$ Portsmouth, 2014. Available at: http://www.visionofbritain.org.uk/maps/sheet/bc_reports_1917/Gloucester_1917 (last viewed: 19 July 2017). 


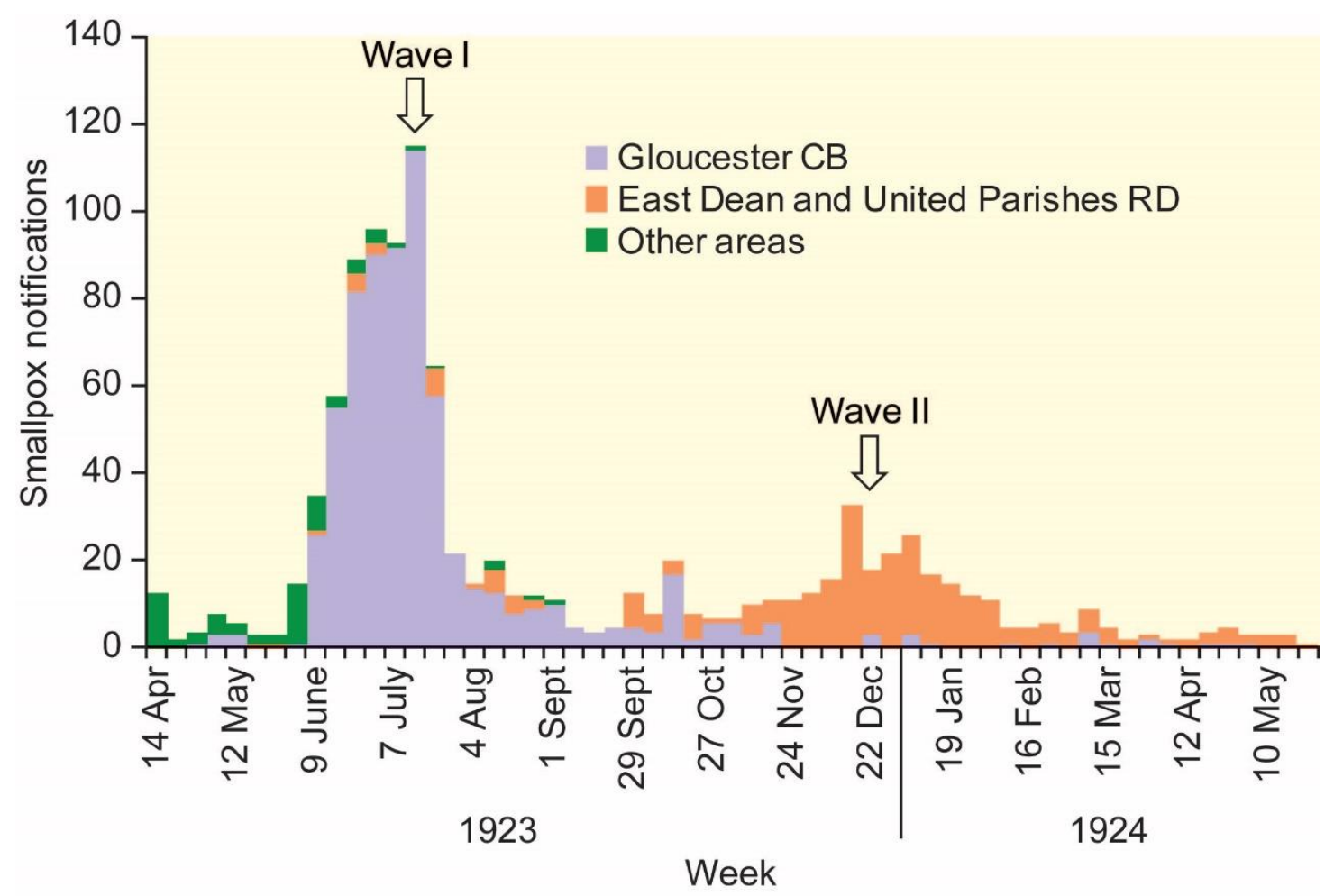

Figure 6. Time series of smallpox notifications in Gloucestershire, April 1923-May 1924. The graph plots, by week, the number of notifications in Gloucester CB, East Dean and United Parishes RD and all other local government areas. The two principal waves of smallpox notifications, associated with Gloucester CB (Wave I) and East Dean and United Parishes RD (Wave II) are highlighted. CB, county borough; RD, rural district. District locations are given in Figure 5. 


\section{NOTES}

${ }^{1}$ Ministry of Health, Small-pox and vaccination, Reports on Public Health and Medical Subjects, 8, London, 1921.

${ }^{2}$ F. Fenner, A. Henderson, I. Arita, Z. Ježek and I.D. Ladnyi, Smallpox and its Eradication, Geneva, 1988, 324-326; M.R. Smallman-Raynor and A.D. Cliff, Atlas of Epidemic Britain: A Twentieth Century Picture, Oxford, 2012, 37-41.

${ }^{3}$ Registrar-General for England and Wales, The Registrar-General's Statistical Review of England and Wales, London, 1923-1935.

${ }^{4}$ Ministry of Health, Annual Report of the Ministry of Health, London, 1922-1936; Chief Medical Officer, On the State of the Public Health: Annual Report of the Chief Medical Officer of the Ministry of Health, London, 1926-1935.

${ }^{5}$ For overviews of smallpox and its control in nineteenth-century Britain, see: C. Creighton, $A$ History of Epidemics in Britain, Volume II. From the Extinction of Plague to the Present Time, Cambridge, 1894, 434-631; C.W. Dixon, Smallpox, London, 1962. A general review of smallpox control efforts at this time is provided by Fenner, Henderson, Arita, Ježek and Ladnyi, Smallpox and its Eradication 245-276.

${ }^{6}$ On the development of vaccination and associated legislation in nineteenth- and early twentieth-century England, see: J.A. Dudgeon, Development of smallpox vaccine in England in the eighteenth and nineteenth centuries, British Medical Journal 1 (1963) 1367-1372; A.S. MacNalty, The prevention of smallpox: from Edward Jenner to Monckton Copeman, Medical History 12 (1968) 1-18; N. Williams, The implementation of compulsory health legislation: infant smallpox vaccination in England and Wales, 1840-1890, Journal of Historical Geography 20 (1994) 396-412.

${ }^{7}$ A. Hardy, Smallpox in London: factors in the decline of the disease in the nineteenth century, Medical History 27 (1983) 111-138; A. Hardy, The Epidemic Streets: Infectious Diseases and the Rise of Preventive Medicine 1856-1900, Oxford, 1993, 110-150. The anti-vaccination movement in nineteenth century England has attracted much attention from historians of medicine. See, for example: A. Beck, Issues in the anti-vaccination movement in England, 
Medical History 4 (1960) 310-321; D. Porter and R. Porter, The politics of prevention: antivaccinationism and public health in nineteenth-century England, Medical History 32 (1988) 231-252; Williams, The implementation of compulsory health legislation; N. Durbach, 'They might as well brand us': working-class resistance to compulsory vaccination in Victorian England, Social History of Medicine 13 (2000) 45-62; N. Durbach, Bodily Matters: The AntiVaccination Movement in England, 1835-1907, Durham, 2005.

${ }^{8}$ Hardy, Smallpox in London 116; Hardy, The Epidemic Streets 114.

${ }^{9}$ Hardy, Smallpox in London; Hardy, The Epidemic Streets 116-128.

${ }^{10}$ Hardy, Smallpox in London; Hardy, The Epidemic Streets 116-128; See also: E.P Hennock, Vaccination policy against smallpox, 1835-1914: a comparison of England with Prussia and Imperial Germany, Social History of Medicine 11 (1998) 49-71; T. Crook, Governing Systems: Modernity and the Making of Public Health in England, 1830-1910, Oakland, 2016, 197-244. ${ }^{11}$ Hardy, Smallpox in London 138. On the Victorian Public Health Acts, see: C. Ham, Health Policy in Britain, sixth edition, Basingstoke, 2009, 8.

${ }^{12}$ Local Government Board, Thirty-first Annual Report of the Local Government Board, 190102. Supplement Containing the Report of the Medical Officer for 1901-02, London, 1901-2, xxxiii-xlii; Local Government Board, Forty-eighth Annual Report of the Local Government Board, 1918-1919. Supplement Containing the Report of the Medical Department for 191819. London, 1919, 83-92.

${ }^{13}$ Smallman-Raynor and Cliff, Atlas of Epidemic Britain.

${ }^{14}$ S.R.M. May, Understanding smallpox: variola minor in England and Wales, 1919-1935, unpublished DPhil thesis, The Queen's College, Oxford University, 1999.

${ }^{15}$ Ministry of Health, Annual Report of the Ministry of Health; Fenner, Henderson, Arita, Ježek and Ladnyi, Smallpox and its Eradication 324-326; Smallman-Raynor and Cliff, Atlas of Epidemic Britain 40-41; S. Rafferty, Epidemic smallpox in England and Wales, 1920-35: variola minor transmission, with special reference to Gloucestershire, 1923-24, unpublished BA (Hons) dissertation, University of Nottingham, 2016.

${ }^{16}$ M. Dworetzky, S. Cohen and D. Mullin, Prometheus in Gloucestershire: Edward Jenner, 1749-1823, Journal of Allergy and Clinical Immunology 112 (2003) 810-814. 
17 G. Williams, Angel of Death: The Story of Smallpox, Basingstoke, 2010, 291-292; Smallman-Raynor and Cliff, Atlas of Epidemic Britain 40; Rafferty, Epidemic smallpox in England and Wales, 1920-35.

${ }^{18}$ See, for example: The Times (London), The smallpox epidemic, 23 June (1923), 9; The Times (London), Smallpox in the West Country, 26 June (1923), 12; Anonymous, The small-pox situation, British Medical Journal 2 (1923) 71; Anonymous, Story of the small-pox epidemic in Gloucester, Lancet 202 (1923) 625-627.

${ }^{19}$ Fenner, Henderson, Arita, Ježek and Ladnyi, Smallpox and its Eradication 191-194; D.L. Heymann, Control of Communicable Diseases Manual, twentieth ed., Washington D.C., 2015, $561-564$

${ }^{20}$ Heymann, Control of Communicable Diseases Manual 562.

${ }^{21}$ Heymann, Control of Communicable Diseases Manual 562.

${ }^{22}$ Smallman-Raynor and Cliff, Atlas of Epidemic Britain 40-41.

${ }^{23}$ Fenner, Henderson, Arita, Ježek and Ladnyi, Smallpox and its Eradication 242-243.

${ }^{24}$ P. Boobbyer, Small-pox in Nottingham, British Medical Journal 1 (1901) 1054.

${ }^{25}$ Fenner, Henderson, Arita, Ježek and Ladnyi, Smallpox and its Eradication 243.

${ }^{26}$ R.P. Garrow, Dual nature of smallpox, British Medical Journal 1 (1925) 1056.

${ }^{27}$ Heymann, Control of Communicable Diseases Manual 564; Anonymous, Views, British Medical Journal 1 (1977) 1476.

${ }^{28}$ Anonymous, Views; K. Ikwueke, The changing pattern of infectious disease, British Medical Journal 289 (1984) 1355-1358; Fenner, Henderson, Arita, Ježek and Ladnyi, Smallpox and its Eradication 326.

${ }^{29}$ Fenner, Henderson, Arita, Ježek and Ladnyi, Smallpox and its Eradication 325.

${ }^{30}$ S.M. Copeman, The relationship of small-pox and alastrim, in: Ministry of Health, Annual Report of the Chief Medical Officer, 1919-1920, London, 1920, 271-282.

${ }^{31}$ Ministry of Health, Second Annual Report of the Ministry of Health, 1920-1921, London, 1921, 18. The outbreak at Middleton, Lancashire, in November 1923 coincided with a byelection for the Parliamentary constituency of Middleton and Prestwich. In the event, a political truce was declared on the recommendation of the medical authorities and the Coalition Liberal 
candidate was returned unopposed. See: The Times (London), Middleton smallpox truce, 15 November (1920), 9.

${ }^{32}$ Ministry of Health, Second Annual Report of the Ministry of Health, 1920-1921 18.

${ }^{33}$ A. McCormick, The notification of infectious diseases in England and Wales, Communicable Disease Report. CDR Review 3 (1993) R19-25.

${ }^{34}$ Registrar-General for England and Wales, Weekly Return of Notifications of Certain Specified Infectious Diseases in England and Wales, London, 1920-36.

${ }^{35}$ For a consideration of the pattern of smallpox activity at the level of local government area, see: M.R. Smallman-Raynor, S. Rafferty and A.D. Cliff, Variola minor in coalfield areas of England and Wales, 1921-34: geographical determinants of a national smallpox epidemic that spread out of effective control, Social Science and Medicine 180 (2017) 160-169.

${ }^{36}$ J.E. Burt, G.M. Barber and D.L. Rigby, Elementary Statistics for Geographers, third edition, New York, 2009, 123.

37 A.D. Cliff, P. Haggett, J.K. Ord and G.R. Versey, Spatial Diffusion: An Historical Geography of Epidemics in an Island Community, Cambridge, 1981, 96-99.

${ }^{38}$ Ministry of Health, Eighth Annual Report of the Ministry of Health, 1926-1927, London, $1927,30$.

${ }^{39}$ Ministry of Health, Sixth Annual Report of the Ministry of Health, 1924-1925, London, 1925, 12; Ministry of Health, Seventh Annual Report of the Ministry of Health, 1925-1926, London, 1926, 16.

${ }^{40}$ Chief Medical Officer, On the State of the Public Health: Annual Report of the Chief Medical Officer of the Ministry of Health for the Year 1927, London, 1928, 25-26.

${ }^{41}$ Chief Medical Officer, On the State of the Public Health: Annual Report of the Chief Medical Officer of the Ministry of Health for the Year 1928, London, 1929, 108.

${ }^{42}$ Smallman-Raynor and Cliff, Atlas of Epidemic Britain 40; Rafferty, Epidemic smallpox in England and Wales, 1920-35.

43 J.E. Sale, L.H. Lohfeld and K. Brazil, Revisiting the quantitative-qualitative debate: implications for mixed-methods research, Quality and Quantity 36 (2002) 43-53. 
44 Gloucestershire County Council, Gloucestershire Archives, http://www.gloucestershire.gov.uk/archives/article/107703/Archives-Homepage last accessed 19 July 2017.

45 Gloucestershire Archives, Gloucester [hereafter GA]: East Dean Rural District Council, Official Documents 1920-40 (DA24/983/1) and Official Minutes 1923-47 (DA24/980); Gloucester Borough Records, Official Minutes 1922-23 (GBR/B3/57); Gloucester County Council (GCC) Archive Project, Official Minutes 1922-24 (GCC/EDU/2/1/2/11); Gloucester Labour Party, Official Minutes 1920-26 (D3128/4/1); Lydney Rural District Council, Official Documents 1921-44 (DA28/135/2); Carter and Co of Newnham-on-Severn (solicitors), Official Documents 1923-58 (D5576/3/4); Maynard W. Colchester-Wemyss (correspondence), 1920/23 (D37/1/316; D37/1/480); Pearson family of Gloucester (correspondence), 1923 (D3558/22); Gloucester Operatic and Dramatic Society, Amateur Society Reports 1914-52 (D4655/2).

${ }^{46}$ The Times (London), Smallpox outbreak, 1 March (1923), 9; The Times (London), Smallpox in the West Country; The Times (London), The smallpox danger, 10 July (1923), 14.

47 The Times (London), Smallpox outbreak; The Times (London), Smallpox in the West Country; The Times (London), The smallpox danger.

${ }^{48}$ On the possible role of Gloucester CB as a source of variola infection in East Dean and United Parishes RD, see: Carter and Co of Newnham-on-Severn, solicitors, The Urban District Council of Awre, The Urban District Council of Coleford and other Councils and The East Dean \& United Districts Joint Hospital Board. Copy. Agreement constituting a Joint Hospital Committee for Small Pox and in the matter of a Provisional Order, 10 July 1923, GA, D5576/3/4.

49 Anonymous, An anti-vaccination center severely affected by smallpox, Journal of the American Medical Association XXVI (1896) 785-786; Durbach, Bodily Matters; Williams, Angel of Death.

${ }^{50}$ W. Hawkins, Walter Hadwen, Gloucestershire History 1 (1987) 10; Williams, Angel of Death. 
${ }^{51}$ Ministry of Health, First Annual Report of the Ministry of Health, 1919-1920. Part I, London, 1920, 149-150.

${ }^{52}$ Ministry of Health, First Annual Report of the Ministry of Health, 1919-1920.

${ }^{53}$ Gloucester Borough Records, City of Gloucester: the epidemic viewed from the hospital, 7 September 1923, GA, GBR/B3/57-38; Gloucester Borough Records, City of Gloucester: Report as to the epidemic of mild smallpox in 1923. With some notes on the cases of chickenpox which have occurred, 6 September 1923, GA, GBR/B3/57-39.

${ }^{54}$ Gloucester Borough Records, Minutes of the Meeting of the Health Committee, 15 June 1923, GA, GBR/B3/57-11; Maynard Colchester-Wemyss to King Rama VI of Siam, 11 May 1920, GA, D37/1/316.

${ }^{55}$ Gloucester Education Committee, Higher Education Sub-Committee, Minutes, 16 June 1923, GA, GCC/EDU/2/1/2/11.

${ }^{56}$ East Dean Rural District Council, Papers relating to establishment and management of Greenway Smallpox Hospital, Littledean, 1920-1927, GA, DA24/983/1-15; East Dean Rural District Council, Surgeon Captain O.W. Andrews to Medical Officers in West Gloucestershire, 5 June 1923, GA, DA24/983/1-17; Gloucester Borough Records, Minutes of the Meeting of the Special Health Sub-Committee, 29 June 1923, GA, GBR/B3/57-22.

${ }^{57}$ See, for example: W. McC. Wanklyn, How to Diagnose Smallpox: A Guide for General Practitioners, Post-graduate Students, and Others, London, 1913; W. McC. Wanklyn, Smallpox diagnosis, British Medical Journal 2 (1922) 1045-1046; W. McC. Wanklyn, The differential diagnosis of small-pox and chicken-pox. Obsolete diagnostic criteria, British Medical Journal 2 (1923) 106-107; W. McC. Wanklyn, A striking case of chicken-pox simulating small-pox. Characteristics which distinguished it, British Medical Journal 1 (1924) 464-465.

${ }^{58}$ Gloucester Borough Records, W.H. Davison to the Members of the Council of the City of Gloucester, 19 June 1923, GA, GBR/B3/57-35; Gloucester Borough Records, City of Gloucester: Report as to the epidemic of mild smallpox in 1923. 
${ }^{59}$ Gloucester Borough Records, City of Gloucester: Report as to the epidemic of mild smallpox in 1923, 4 September 1923, GA, GBR/B3/57-37; Maynard Colchester-Wemyss to King Rama VI of Siam, 4 July 1923, GA, D37/1/480.

${ }^{60}$ Maynard Colchester-Wemyss to King Rama VI of Siam.

${ }^{61}$ Gloucester Borough Records, Minutes of a Meeting of the Health Committee, 5 October 1923, GA, GBR/B3/57-34.

${ }^{62}$ Anonymous, An anti-vaccination center severely affected by smallpox; The Times (London), The Assizes, 18 February (1896), 11.

${ }^{63}$ Lydney Rural District Council, Surgeon Captain O.W. Andrews to Lydney Rural District Council, 28 February 1923, GA, DA28/135/2-4; Gloucester Borough Records, W.H. Davison to the Members of the Council of the City of Gloucester.

${ }^{64}$ Gloucester Borough Records, Special Meeting of the Health Committee, 6 June 1923, GA, GBR/B3/57-6; N.M. Herbert, A History of the County of Gloucester: Volume 4, The City of Gloucester, London, 1988.

${ }^{65}$ Gloucester Borough Records, W.H. Davison to the Members of the Council of the City of Gloucester.

${ }^{66}$ Gloucester Borough Records, City of Gloucester: Report as to the epidemic of mild smallpox in 1923. On the development of the obligations and legal responsibilities of general practitioners in relation to the diagnosis and notification of infectious diseases, see: G. Mooney, Public health versus private practice: the contested development of compulsory infectious disease notification in late-nineteenth-century Britain, Bulletin of the History of Medicine 73 (1999) 238-267; G. Mooney, Intrusive Interventions: Public Health, Domestic Space, and Infectious Disease Surveillance in England, 1840-1914, Rochester, NY, 2015, 40-65.

${ }^{67}$ Gloucester Borough Records, Minutes of the Special Health Sub-Committee, 11 June 1923, GA, GBR/B3/57-8; Anonymous, Story of the small-pox epidemic in Gloucester.

${ }^{68}$ Gloucester Borough Records, Minutes of the Special Health Sub-Committee, 13 June 1923, GA, GBR/B3/57-10; Gloucester Borough Records, Minutes at an Emergency Meeting of the Health Committee, 23 June 1923, GA, GBR/B3/57-17. 
${ }^{69}$ Gloucester Borough Records, Minutes at an Emergency Meeting of the Health Committee; Anonymous, Story of the small-pox epidemic in Gloucester 625.

${ }^{70}$ Gloucester Borough Records, Minutes of a Meeting of the Council of the City of Gloucester, 27 June 1923, GA, GBR/B3/57-20.

${ }^{71}$ Gloucester Borough Records, Minutes of a Special Meeting of the Health Committee, 2 July 1923, GA GBR/B3/57-24; The Times (London), The smallpox menace, 2 July (1923), 14.

${ }^{72}$ The Gloucester Journal, Municipal elections, 3 November (1923), 10.

${ }^{73}$ The Gloucester Journal, Municipal elections.

${ }^{74}$ Gloucester Borough Records, W.H. Davison to the Members of the Council of the City of Gloucester; Gloucester Borough Records, City of Gloucester: Report as to the epidemic of mild smallpox in 1923.

${ }^{75}$ Gloucester Borough Records, W.H. Davison to the Members of the Council of the City of Gloucester.

${ }^{76}$ Gloucester Borough Records, Minutes of the Special Health Sub-Committee, 21 June 1923, GA, GBR/B3/57-16.

${ }^{77}$ Gloucester Borough Records, City of Gloucester: Report as to the epidemic of mild smallpox in 1923.

78 Gloucester Borough Records, Health Committee. Special Meeting, 6 April 1923, GA, GBR/B3/57-4; Gloucester Labour Party, Minutes of General Committee held at the Labour Club, 25 June 1923, GA, D3128/4/1-1; East Dean Rural District Council, Papers relating to establishment and management of Greenway Smallpox Hospital, Littledean, 1920-1927, 29 November 1923, GA, DA24/980-2; Gloucester Borough Records, Minutes of a Special Meeting of the Health Committee, 25 June 1923, GA, GBR/B3/57-18. For perspectives on disinfection and schools in the monitoring and control of infectious diseases in nineteenth and early twentieth century England, see Mooney, Intrusive Interventions 93-153.

79 Fenner, Henderson, Arita, Ježek and Ladnyi, Smallpox and its Eradication 324-326; Smallman-Raynor and Cliff, Atlas of Epidemic Britain 40-41.

${ }^{80}$ Ministry of Health, Small-pox and vaccination; Ministry of Health, Annual Report of the Ministry of Health. 
${ }^{81}$ Smallman-Raynor, Rafferty and Cliff, Variola minor in coalfield areas of England and Wales, 1921-34.

${ }^{82}$ G. Newman, The State of Public Health: Sir George Newman's Report For 1931, British Medical Journal 2 (1932) 636.

${ }^{83}$ Registrar-General for England and Wales, The Registrar-General's Statistical Review for England and Wales for the Year 1935 (New Annual Series no. 15). Tables. Part I. Medical, London, 1936, 373.

${ }^{84}$ We note here that East Dean and United Parishes RD had a substantial mining industry associated with the Forest of Dean Coalfield. In light of the established geographical association between coal mining and variola minor at the national level, this localised focus of disease activity would seem to merit closer investigation. See: Smallman-Raynor, Rafferty and Cliff, Variola minor in coalfield areas of England and Wales, 1921-34.

${ }^{85}$ D.L. Ross, Leicester and the anti-vaccination movement, 1853-1889, Transactions of the Leicestershire Archaeological and Historical Society 43 (1967-1968) 35-44; S.F. Fraser, Leicester and smallpox: the Leicester Method, Medical History 24 (1980) 315-332; Durbach, Bodily Matters 41.

86 Anonymous, Small-pox in London, British Medical Journal 2 (1922) 819-820; Chief Medical Officer, On the State of the Public Health: Annual Report of the Chief Medical Officer of the Ministry of Health for the Year 1926, London, 1927, 40.

${ }^{87}$ Ministry of Health, Seventh Annual Report of the Ministry of Health 17.

${ }^{88}$ Ministry of Health, Annual Report of the Ministry of Health; Chief Medical Officer, On the State of the Public Health.

${ }^{89}$ Chief Medical Officer, On the State of the Public Health 41 (emphasis in original).

${ }^{90}$ See, for example: The Times (London), Smallpox patients train journey, 26 July (1921), 7; The Times (London), News in brief, 1 September (1921), 7; F.A. Sharpe, Small-pox: an unrecognized outbreak, British Medical Journal 2 (1924) 621; Anonymous, Small-pox in the north of England, British Medical Journal 1 (1927) 147-149.

${ }^{91}$ See note 57. 
${ }^{92}$ Ministry of Health, Ninth Annual Report of the Ministry of Health, 1927-1928, London, $1928,39$.

93 Such were the circumstances in parts of Northumberland in 1924, Durham and Northamptonshire in 1925 and the West Riding of Yorkshire in 1927. See: Chief Medical Officer, On the State of the Public Health: Annual Report of the Chief Medical Officer of the Ministry of Health for the Year 1925, London, 1926, 31-41; Anonymous, Small-pox in the north of England.

${ }^{94}$ For reports on case concealment in high incidence areas (including Nottingham, Derby, South Shields and Sheffield), see: The Times (London), The smallpox danger, 12 January (1923), 8; Chief Medical Officer, On the State of the Public Health 36; The Times (London), News in brief, 3 March (1926), 18; Anonymous, Small-pox in the north of England.

${ }^{95}$ Chief Medical Officer, On the State of the Public Health 42.

${ }^{96}$ Chief Medical Officer, On the State of the Public Health 42. On the circumstances in Ashington UD, see: Chief Medical Officer, On the State of the Public Health 36.

${ }^{97}$ Ministry of Health, First Annual Report of the Ministry of Health, 1919-1920 83-84.

${ }^{98}$ Ministry of Health, Seventh Annual Report of the Ministry of Health, 1925-1926 16.

99 S. Mills, Cultural-historical geographies of the archive: fragments, objects and ghosts, Geography Compass 7 (2013) 701-713; J. Duncan, Notes on emancipatory collaborative historical research, Historical Geography 29 (2001) 65-67.

${ }^{100}$ H. Markel, A.M. Stern, J.A. Navarro, J.R. Michalsen, A.S. Monto and C. DiGiovanni, Nonpharmaceutical influenza mitigation strategies, US communities, 1918-1920 pandemic, Emerging Infectious Diseases 12 (2006) 1961-1964; H. Markel, A.M. Stern and M.S. Cetron, Theodore E. Woodward award: non-pharmaceutical interventions employed by major American cities during the 1918-19 influenza pandemic, Transactions of the American Clinical and Climatological Association 119 (2008) 129-138; A.M. Stern, M.S. Cetron and H. Markel, The 1918-1919 influenza pandemic in the United States: lessons learned and challenges exposed, Public Health Reports 125:S3 (2010) 6-8; A.M. Stern, M.B. Reilly, M.S. Cetron and H. Markel, "Better off in school": school medical inspection as a public health 
strategy during the 1918-1919 influenza pandemic in the United States, Public Health Reports 125:S3 (2010) 63-70.

${ }^{101}$ Markel, Stern, Navarro, Michalsen, Monto and DiGiovanni, Nonpharmaceutical influenza mitigation strategies.

${ }^{102}$ Fenner, Henderson, Arita, Ježek and Ladnyi, Smallpox and its Eradication 245-276.

${ }^{103}$ Hardy, Smallpox in London 121.

${ }^{104}$ Fenner, Henderson, Arita, Ježek and Ladnyi, Smallpox and its Eradication 539-592.

${ }^{105}$ O. Yaqub, S. Castle-Clarke, N. Sevdalis and J. Chataway, Attitudes to vaccination: a critical review, Social Science and Medicine 112 (2014) 1-11.

${ }^{106}$ See, for example: R.W. Sutter, L.E. Markowitz, J.M. Bennetch, W. Morris, E.R. Zell and S.R. Preblud, Measles among the Amish: a comparative study of measles severity in primary and secondary cases in households, Journal of Infectious Diseases 163 (1991) 12-16.

${ }^{107}$ R.E. Casiday, Children's health and the social theory of risk: insights from the British measles, mumps and rubella (MMR) controversy, Social Science and Medicine 65 (2007) 1059-1070; Smallman-Raynor and Cliff, Atlas of Epidemic Britain 130, 181-183.

${ }^{108}$ Dixon, Smallpox 447.

${ }^{109}$ Burt, Barber and Rigby, Elementary Statistics for Geographers 123.

${ }^{110}$ Cliff, Haggett, Ord and Versey, Spatial Diffusion 96-99. 